\title{
Hacia una (de)construcción del teatro breve de Manuel Bretón de los Herreros
}

\section{Towards a (De)construction of Manuel Bretón de los Herreros Short Plays}

\author{
Francisco Javier Fernández Urenda \\ Longwood University
}

\begin{abstract}
RESUMEN
El teatro breve de Manuel Bretón de los Herreros (1796-1873) ha sido tradicionalmente identificado con un corpus de veinticinco comedias en uno o dos actos recopiladas en la edición póstuma de las obras del escritor de 1883-1884. El presente ensayo sigue un criterio totalizador y aporta dieciocho comedias breves adicionales que completan el corpus definitivo de la dramaturgia menor de Bretón. Bajo la hipótesis de la existencia de un proceso de autocensura que elidió progresivamente dicho conjunto de dieciocho obras, este trabajo argumenta cómo el autor, los biógrafos y los críticos posteriores favorecieron la irregular recepción crítica de este significativo subgénero dramático. Conceptos como escritura politizada y autocensura consciente pasan a incorporarse así a los estudios sobre Bretón de los Herreros.
\end{abstract}

Palabras Clave: Autocensura; políticos y literatura; propaganda; teatro breve; Bretón de los Herreros; liberalismo; política general de la verdad; Foucault.

\begin{abstract}
The short plays of Manuel Bretón de los Herreros (1796-1873) have been traditionally identified with a group of twenty five plays, composed in one or two acts, which were compiled within the posthumous edition of his works in 1883-1884. The present essay follows a comprehensive criterion and includes eighteen additional writings that complete the corpus of the Bretón de los Herreros' short plays. Under the hypothesis of the existence of a self-censorship process that progressively elided such a group of comedies, this article argues how the author, his biographers, and his later critics favoured an irregular literary criticism about this significant dramatic sub-genre. Concepts like political writing and conscious self-censorship will be incorporated here to the studies about Bretón de los Herreros.
\end{abstract}

Key words: Self-censorship; Politics and literature; Propaganda; Short plays; Bretón de los Herreros; Liberalism; 'General politics' of truth; Foucault. 


\section{INTRODUCCIÓN}

El escueto prólogo de la Corona poética (1873) dedicada a honrar la muerte del escritor Manuel Bretón de los Herreros (1796-1873) ofrece varias noticias que sugieren la popularidad que entonces aún gozaba el recién desaparecido dramaturgo. Se menciona, por ejemplo, que miembros de la empresa del Teatro Español participaron en la comitiva fúnebre y que se inició una serie de veinticuatro representaciones de varias de sus piezas (Corona, 1873: 3). El objetivo de aquella iniciativa era recaudar fondos para elevar un mausoleo dedicado a la memoria del autor. Como era habitual en ese tipo de actos, durante las representaciones se leyeron composiciones elegiacas solicitadas previamente a «primeros escritores», si bien la empresa deploraba que «no hayan respondido todos a este llamamiento»(Corona, 1873: 4). Hartzenbusch y Rodríguez Rubí aparecen como nombres destacados, pero no así el íntimo amigo y padrino de bodas de Bretón, Mariano Roca de Togores, marqués de Molins. Hay que esperar hasta 1883 para que la imprenta refrende tanto la importancia literaria de la figura de Bretón como la confirmación del aprecio personal que hacia él sentía el marqués de Molins. En ese año vieron la luz dos publicaciones determinantes para la recepción crítica del escritor: Bretón de los Herreros: recuerdos de su vida y de sus obras, a cargo de Mariano Roca de Togores; y la edición póstuma de las obras del autor al cuidado de su sobrino, Cándido Bretón y Orozco.

Ambas publicaciones revisten especial importancia para el conocimiento y estudio del teatro breve de Bretón de los Herreros. En sus recuerdos, Roca de Togores (1883: 264-267) daba cuenta de la entidad y relevancia de un grupo de comedias bretonianas escritas en uno o dos actos como máximo. La edición póstuma de las obras de Bretón de los Herreros (1883-1884) dotó de visibilidad a este subgénero al recopilar las veinticinco piezas que la crítica posterior entendió como el corpus del teatro menor bretoniano. Se creyó de forma unánime desde entonces que el marco temporal de su creación y desarrollo discurrió desde 1835, año del estreno de El hombre gordo, «inicio de una dedicación al teatro breve» (Muro, 2000, I: 16), hasta 1862, cuando Bretón publicó Entre santa y santo... en una tirada especial de la publicación periódica El Museo de Familias.

Sin embargo, pese a dicha creencia generalizada, la nómina de sus obras breves originales es mucho más abultada y su composición se inició en 1828 y no en 1835. Así, como expondré en las páginas siguientes, Bretón, además de las conocidas veinticinco «comediejas», también escribió un conjunto de obras en uno o dos actos cuyos contenidos eran explícitamente ideológicos. Pasado el tiempo, su creador se esforzó en ocultar la existencia de esos textos incurriendo en un ejercicio de autocensura. Haciendo válidas las palabras de Lefevere de que «Cuando una cultura llega a tener una imagen canonizada de su pasado, tiende a eliminar aquellas figuras y rasgos de ese pasado que 
no se ajustan a esa imagen» (1997: 141), llegaron a imponerse los argumentos estéticos, aunque veladamente políticos, del propio autor justificando la elisión y el olvido. Tras la muerte del poeta, el proceso de autocensura se completó con una irregular recepción crítica de su literatura y de su teatro menor en particular.

La ausencia de monografías o trabajos publicados que, desde cualquier marco teórico o crítico, aborden el estudio y análisis del señalado conjunto de comedias breves de contenidos políticos, permite comprobar la efectividad del proceso de autocensura. Esto es especialmente significativo si se considera el contexto de revalorización de la figura y la obra del dramaturgo riojano que se extiende a las últimas décadas. Una somera recapitulación bibliográfica ofrece ejemplos reseñables como las monografías y ediciones de Flynn (1978), Garelli (1983), Muro (1991; 1999; 2000), Bravo (2002), Miret (2004) y Ballesteros (2012). Dentro del ámbito de la crítica e historiografía literaria en su sentido más lato, también han contribuido a dicha revalorización los juicios y opiniones de Caldera (1978), Gies (1988; 1996), o Rubio Jiménez (1998), entre otros.

\section{El TEATRO BREVE AUTOCENSURADO}

Entre la bibliografía especializada destaca, como es lógico, el interés dedicado a su ingente producción dramática, que se extendió desde el año 1824, fecha del estreno de su primera comedia, A la vejez, viruelas, hasta la representación de su última obra, Los sentidos corporales, en 1867. Durante ese lapso de tiempo, Bretón pugnó por estar presente en los escenarios pese a la sucesión de diferentes sensibilidades estéticas como el neoclasicismo posmoratiniano, el costumbrismo, el romanticismo y, finalmente, la «alta comedia». Desde sus comienzos, marcados por los avatares políticos de la represión absolutista tras el trienio liberal (1820-1823), destacaron sus estrenos de obras originales en un contexto teatral en franca decadencia (Díez y Rozas, 1965: 10-16). Tanto la guerra como el exilio de intelectuales habían afectado a la calidad y cantidad de estrenos originales (Gies, 1996: 124) y abundaban las adaptaciones de comedias del Siglo de Oro y traducciones, en su mayoría del teatro francés. No en vano, Mesonero Romanos aseguraba en su artículo «Las traducciones», publicado en 1840, que España era una «nación traducida» (1967, II: 277), debido a la ingente cantidad de este tipo de composiciones que copaban los escenarios madrileños.

Aunque el propio Bretón se congratulaba en 1831 de la creciente presencia de estrenos originales entre la multitud de traducciones y adaptaciones de obras del Siglo de Oro español (Díez y Rozas, 1965: 158-159), la realidad es que la labor de traducción enriqueció al dramaturgo y sirvió como piedra de toque para refinar su teatro. Son precisamente las traducciones las que indu- 
jeron a Bretón de los Herreros a dedicarse a la composición de este tipo de obras. Como ya quedó señalado anteriormente, lejos de considerar el estreno de El hombre gordo (1835) como el inicio de la serie del teatro breve bretoniano, fue durante el año 1828 cuando Bretón de los Herreros tradujo sus dos primeras piezas breves en un acto para, meses después, estrenar su primera comedia breve de circunstancias: Amor y ligereza o El ensayo (1828). Para el día del estreno de esta pieza en dos actos, ya se habían representado Las confesiones difíciles, basada en Les aveux difficiles de Vigée, y El legado o El amante singular, adaptación de Le legs de Marivaux. A ellas se unirá en los años siguientes, de acuerdo al catálogo de Cándido Bretón (1883b), una nutrida nómina de piezas breves traducidas de autores franceses como Bayard, Carmouche, Desvergers, Destouches, Delavigne, Devilleneuve, Dieulafoy, Duvert, Mélesville, Charles Duveyrier, Ménissier, Moreau, Picard, Poirson, Rosier, Victor Varin y Vigée. En muchos casos se trataba de colaboraciones entre éstos y el fecundo dramaturgo francés Eugène Scribe (1791-1861), a quien Bretón pretendía emular (Roca, 1883: 265). De él apreciaba su concepto teatral de la pièce bien faite y su capacidad de crear situaciones cómicas a través de los quid pro quo. El que la crítica posterior haya tomado El hombre gordo como piedra angular sobre la que se construye el género menor bretoniano refuerza la idea de la importancia de la influencia de Scribe, puesto que dicha comedia es el primer y más genuino intento bretoniano de imitación del vaudeville francés (Muro, 1999, II: 70-75; Bravo, 2002: 92-93).

Además de las influencias vodevilescas, el teatro breve del autor riojano se enriquece con elementos neoclásicos. Es reseñable, por ejemplo, la influencia de la comedia moratiniana (Bravo, 2002: 81-89), cuyo modelo considera superior incluso al de Corneille o Racine (Dengler, 1996: 441), a quienes tradujo en sus primeros años. Del autor de El sí de las niñas, toma específicamente no ya su tendencia a la moralización, presente también en varios de los modelos franceses que habitualmente traducía como Marivaux, Néricault y Picard, sino también el respeto a las reglas, la temática del matrimonio y, en algunas de sus primeras comedias, la incorporación del personaje bienpensante e ilustrado. Como curiosidad, habría que indicar la presencia de microtextos alusivos a La comedia nueva en El poeta y la beneficiada (1838), obra breve que desvela en clave cómica la dedicación de Bretón de los Herreros a la composición de ese tipo de piezas reclamadas por los actores y actrices para sus funciones de beneficio. Asimismo, respecto a las obras autocensuradas, pueden también apreciarse evidentes concomitancias argumentales respecto a El sí de las niñas en una de sus últimas comedias breves: El Ebro (1857). Por otra parte, Bravo Vega (2002: 78) también ha notado cómo Bretón reutiliza ciertos elementos propios del sainete neoclásico como el lenguaje paremiológico y algunas fórmulas de comicidad presentes en Ramón de la Cruz. Dado que el sainete se define a grades rasgos por el humor y su marcado interés crítico (Palacios, 1988: 143-144), su condición de precedente de la comedia 
breve costumbrista resulta reforzada. No en vano, la importancia de la comicidad verbal en las piezas menores es signo distintivo del teatro del autor (Bravo, 1998a).

La tradición del drama aurisecular español igualmente supone una notable influencia para Bretón de los Herreros, quien reelabora soluciones propias de las formas populares del entremés y de las comedias del Siglo de Oro. La relación entre la comedia menor bretoniana y dichos precedentes también fue desarrollada por Bravo Vega, para quien

El «género de Bretón» se halla delimitado entre el entremés de figuras y la comedia de figurón. La intención cómica es palpable, el enredo es abundante, la actualización de los tipos áureos es evidente y, en ocasiones, el autor no evita mostrar sus propias fuentes. Resulta de todo ello un sustrato clásico dominante desde el que Bretón construye su teatro a través de determinados resortes (1998b: $324)$.

En un estudio posterior, además de trazar detalladamente los mecanismos teatrales heredados de los sainetes de Ramón de la Cruz y Moratín hijo y las relaciones con el vaudeville francés, el mismo crítico aquilata las influencias áureas de la comedia breve de Bretón de los Herreros. Entre los recursos más determinantes, Bravo Vega (2002: 31-38) señala el uso de la burla entremesil, en ocasiones reversible, y la utilización de tipos y figurones habituales en el teatro aurisecular. En la transición del entremés de figuras a la comedia de figurón es donde contempla una de las características más notables del teatro menor bretoniano. De ahí que concluya que «La depuración de una materia rica y variada, como es la entremesil, y su encaje en los planteamientos de la comedia áurea permiten a Bretón obtener una fórmula cómica que garantiza la arquitectura de su teatro breve» (Bravo, 2002: 49-50).

Pese a la meritoria elaboración de este tipo de composiciones, con las que aspiraba a crear un subgénero imbricado en el costumbrismo decimonónico y genuinamente español, los juicios del propio Bretón de los Herreros no parecen conceder excesivo mérito a su teatro menor. En su correspondencia con Roca de Togores, le refiere su dedicación a un conjunto de obras compuestas entre diciembre de 1837 y abril de 1838: Medidas extraordinarias o Los parientes de mi mujer, Ella es él, El poeta y la beneficiada, El pro y el contra y El hombre pacífico. Junto con sus reflexiones sobre la dificultad de construir unos «juguetes dramáticos» con calidad similar a las comedias extensas, Bretón cuestiona su utilidad, que según él quedaba reducida a la necesidad de escribir obras para satisfacer compromisos con los actores que planeaban funciones de beneficio. La terminología con la que designaba a estas composiciones, si bien lejos de ser despectiva, no permite apreciar la importancia que posee el teatro breve en su actividad literaria. Diseminados a lo largo de la correspondencia enviada a Roca de Togores el 16 de marzo de 1838, aparecen términos como «comediejas», «fabulillas», «juguetes», «sainetillos», «dra- 
mitas», «poemitas»y «pasatiempos» (Roca, 1883: 264-267). Fue quizás este aparente desdén lo que desvió la atención de la crítica contemporánea de estas creaciones, sin duda eclipsadas por estrenos más trascendentales como Marcela o ¿A cuál de los tres? (1831), Muérete iy verás!... (1837), o El pelo de la dehesa (1840). La excepción se encuentra en el posterior juicio de Roca de Togores (1893: 17-18), quien dos décadas después de la muerte de su amigo reflexionó positivamente sobre las comedias Ella es él, El pro y el contra, Mi secretario y yo y A lo hecho pecho, meritorias de ser consideradas genuinamente bretonianas como lo eran obras extensas antes señaladas.

Sin negar estas particularidades, y a pesar de que la caracterización del subgénero breve parece delimitada desde los propios comentarios de Bretón y sus críticos contemporáneos, hay que advertir que dichos juicios son parciales debido a que han sido referidos a propósito de un corpus incompleto del que se ha excluido una parte significativa de obras. La crítica ha articulado una serie de discursos relativos al teatro menor bretoniano siempre suponiendo que el dramaturgo riojano compuso un total de veinticinco piezas breves que fueron recopiladas en la edición póstuma de sus obras. Sin embargo, el número total de obras que pueden ser incluidas en un catálogo del teatro menor de Bretón de los Herreros asciende a cuarenta y tres. Con la excepción del documentado trabajo de Ballesteros (2012), que incluye noticias de la secuencia de estrenos y manuscritos bretonianos hasta la temporada teatral de 1839-1840, y del reciente estudio donde se detallan las particularidades de la génesis de las obras en cuestión (Fernández, 2014), este grupo de comedias breves no ha merecido una sistemática consideración crítica. Pese a que sus elementos integrantes son susceptibles de ser analizados según los rasgos y caracterización de las obras breves que sí trascendieron, éstos fueron sometidos a un proceso de autocensura consciente que involucró tanto a su creador como a la crítica actual y contemporánea del autor. El silencio y la exclusión interesados y la desatención de su estudio por motivos esencialmente estéticos o de valor literario llegaron a conformar dos catálogos notablemente diferenciados que en estas páginas se pretende unificar: por una parte, el conjunto de veinticinco comedias consideradas tradicionalmente como el corpus del teatro breve de Bretón de los Herreros, transmitido a través de las ediciones recopilatorias de las obras del autor; por otra, el grupo de dieciocho obras breves que han sufrido el proceso de autocensura y que se incorporan aquí al acervo literario bretoniano.

La distinción de ambos conjuntos se fundamenta en primer lugar en la labor bibliográfica de Cándido Bretón y Orozco. En el apartado dedicado a las «obras dramáticas» que se encuentra en su catálogo de obras bretonianas (Bretón y Orozco, 1883b), ofreció, en la medida de lo posible, información sucinta sobre el estreno, ediciones, lenguaje literario utilizado y noticias adicionales sobre un total de 177 composiciones, incluyendo también traducciones y refundiciones del teatro del Siglo de Oro español. Este catálogo ha sido 
el indefectible punto de inicio para los estudios posteriores de la obra de Bretón de los Herreros, especialmente la dramaturgia. Críticos y bibliógrafos como Roca de Togores (1883: 546-555), Le Gentil (1909: 528-532) y Carrión y Delgado (1996: 39-76), por ejemplo, lo tomaron como referencia indispensable e incluso, como fue el caso de Le Gentil, llegó a ser reproducido de manera casi literal. Carrión y Delgado aportaron como novedad una coherente clasificación de las obras dramáticas que diferenciaba tipos y subtipos como las composiciones originales y las traducciones, las ediciones sueltas y las recopilaciones, los manuscritos y los impresos. Es llamativo que, si bien ya el propio Cándido Bretón (1883a: VIII) aludió vagamente a la existencia de un grupo de comedias ad hoc en su estudio biográfico del escritor riojano, Carrión y Delgado distingan entre las piezas extensas y las comedias breves y de circunstancias. Entre estas últimas se cuenta un total de dieciséis composiciones que, según mostraré más adelante, su autor escribió de acuerdo a diferentes motivaciones políticas. Para completar el catálogo provisional de dieciocho comedias de circunstancias aludidas, es necesario revisar repertorios bibliográficos adicionales como los de Menarini, Garelli, San Vicente y Vedovato (1982), Franco (1984) y González y Penas (1992), así como las recopilaciones de estrenos recogidos en las carteleras teatrales de Madrid (Simón, 1961; Herrero Salgado, 1963) y otras provincias (Aguilar, 1968). Todos ellos, junto con las noticias específicas de los estrenos aparecidas en los periódicos del momento, permiten dar forma al corpus del teatro breve autocensurado de Bretón de los Herreros.

Se incorporarán aquí dos comedias breves hasta ahora no consideradas: Un faccioso menos (1837) y La sombra de Isabel I (1843). De esta última, no han podido localizarse ejemplares impresos o manuscritos, pero se conservan noticias sobre su representación en diferentes periódicos como la Gaceta de Madrid (4.XII.1843, p. 4), la Gaceta literaria y musical de España (8.XII.1843, p. 87) y en los «Programas de la función que el Excmo. Ayuntamiento determinó dar por convite en el Teatro del Príncipe para celebrar la mayoría de edad y juramento de S.M. la Reina $\mathrm{D}^{\mathrm{a}}$ Isabel $2^{\mathrm{a}}{ }_{»^{1}}$. Aunque dichas noticias no aluden a la autoría de la pieza, algo hasta cierto punto habitual en las comedias de circunstancias, Menarini (Menarini, Garelli, San Vicente y Vedovato, 1982) confirma que fue escrita en colaboración con Tomás Rodríguez Rubí y Ventura de la Vega. Dicho repertorio ofrece una fecha de estreno equivocada, si bien las fuentes documentales señaladas reafirman la del día 3 de diciembre de 1843.

Tomando como referencia a Cándido Bretón y el resto de catálogos bibliográficos posteriores, la secuencia cronológica del teatro menor autocensurado seguiría el siguiente orden:

\footnotetext{
${ }^{1}$ Archivo de la Villa de Madrid: Secretaría, 3-395-8.
} 
1.-Amor y ligereza o El ensayo (8.VIII.1828). 2 actos.

2.-El rival de sí mismo (11.VIII.1828). 1 acto.

3.-El templo de Himeneo (12.XII.1829). 1 acto.

4.-La sorpresa (24.VII.1830). 1 acto.

5.-El músico y el poeta (1832; estreno 30.V.1833). 1 acto.

6.-El templo de la Gloria (23.VI.1833). 1 acto.

7.-El triunfo de la Inocencia (25.VI.1833). 1 acto.

8.-Los carlistas en Portugal o La tremenda expedición (15.IV.1834). 1 acto.

9.-El plan de un drama o La conspiración (22.X.1835). 1 acto.

10.-Otro diablo predicador o El liberal por fuerza (16.XI.1835). 1 acto.

11.-1835 y 1836 o Lo que es y lo que será (5.XII.1835). 2 actos. Colaboración con Juan de Grimaldi y Ventura de la Vega.

12.-Un faccioso menos (24.XII.1835). 1 acto.

13.-Las improvisaciones (30.I.1837). 1 acto.

14.-La ponchada (1.X.1840). 1 acto.

15.- El carnaval de los demonios (3.I.18432; publicado en 18.II.1844). 1 acto.

16. - La sombra de Isabel I (3.XII.1843). 1 acto. Colaboración con Rodríguez Rubí y Ventura de la Vega.

17.-El Ebro (19.VII.1857). 1 acto.

18.-El peluquero y el cesante (VII.1861). 1 acto.

Frente a las veinticinco comedias breves que podrían considerarse el corpus tradicional del teatro menor de Bretón de los Herreros, este corpus autocensurado se revela de especial importancia porque, ya sólo cuantitativamente, supone casi la mitad del repertorio de sus piezas escritas en uno o dos actos. Bien es cierto que entre las dieciocho obras autocensuradas La sorpresa, 1835 y 1836 o Lo que es y lo que será y La sombra de Isabel I se hallan actualmente perdidas y sus impresos o manuscritos no han trascendido. No obstante, la posibilidad de llegar a acrecentar el catálogo de dramas bretonianos con nuevas incorporaciones era algo que reconocía el propio Cándido Bretón (1883a: XVIII) y que el trabajo de Ballesteros (2012) parece confirmar después de ofrecer como válida la autoría de las traducciones Una hora de ausencia y Dos palabras o una noche en el bosque. Esta última, atribuida en un principio al hermano del dramaturgo, Antonio Bretón, es considerada por la estudiosa como original dadas las semejanzas caligráficas con otros autógrafos bretonianos (Ballesteros, 2012, I: 357). Con todo ello, la delimitación de este conjunto de comedias breves y su incorporación a los estudios bretonianos arroja una sugerente hipótesis a propósito del proceso de génesis del subgénero. Así, con la referencia de la fecha del estreno de El hombre gordo en enero de 1835, año en el que se intensifica el trabajo de Bretón como escritor de piezas circunstanciales, cabe suponer una evolución en la dramaturgia y estilo bretonianos similar a la apreciada en sus comedias extensas. El que no haya podido establecerse una distinción similar hasta ahora se fundamenta en la desatención que mereció el corpus autocensurado desde tiempos de su autor.

\footnotetext{
${ }^{2}$ Citado por Roca de Togores (1883: 273).
} 
La acotación del subgénero del teatro breve permite valorar la creación bretoniana desde presupuestos totalizadores, evaluando así su dimensión y significación reales. El mencionado proceso de génesis está sin duda vinculado a los sucesivos estadios creativos por los que discurrió su literatura. De hecho, cabe insistir en que el período de composición del conjunto de comedias breves autocensuradas, entre 1828 y 1861, se extiende hasta la práctica totalidad del periplo creador de Bretón.

Respecto al teatro extenso, esta particular longevidad creativa ha propiciado el debate a propósito de la transición en Bretón de los Herreros de una escritura con evidentes influjos moratinianos a la consecución de un estilo más personal e identificativo que la crítica contemporánea al autor calificó de «género de Bretón» (Ochoa, 1836: 3). Entre los que aseguran que la dramaturgia de Bretón nunca dejó de ser neoclásica en su esencia, se encuentran Consiglio (1947), Cook (1959: 497-505) y Hesse (Bretón de los Herreros, 1969). Frente a sus opiniones, además de la del propio Ochoa, se contraponen las de Roca de Togores (1883; 1893), Alonso Cortés (1928: XIII) y, mucho más recientemente, Gies, quien subraya además que la adopción de la pátina moratiniana se debió a la necesidad de abrirse paso en el intrincado mundo teatral madrileño fernandino (Gies, 1996: 99-100).

En lo que concierne al teatro breve, nunca ha podido hacerse una afirmación en relación a la transición de las formas neoclásicas a las netamente costumbristas o bretonianas, puesto que en el año 1835, fecha que la crítica aceptaba como inicio de la dedicación al teatro breve del escritor, su estilo estaba ya definido y ensayado con éxito en los escenarios de Madrid y Sevilla. No obstante, para el estreno de El hombre gordo, ya se habían representado con diferente éxito un total de siete comedias breves y se había publicado Los carlistas en Portugal o La tremenda expedición en las páginas del diario madrileño El Universal. La mayoría de éstas responde a parámetros estéticos neoclásicos, especialmente por la inclusión de elementos mitológicos y alegóricos, que llegan a articular completamente las loas borbónicas de El templo de Himeneo, El templo de la Gloria y El triunfo de la Inocencia. Sin embargo, se debe prestar especial atención a El músico y el poeta, puesto que fue la primera comedia original compuesta después de un lapso de un año dedicado a las traducciones tras el exitoso estreno de Marcela o ¿A cuál de los tres? a finales de 1831. Su atenta lectura confirma que Bretón se había decidido entonces a dar un giro notable a su sistema dramático y El músico y el poeta atestigua el paso dado con Marcela en lo que se refiere a la adopción de la riqueza métrica y el refinamiento de los modelos dramáticos del entremés y la comedia auriseculares. De ahí la presencia insoslayable de la estructura entremesil del desfile con la que se articula dicha pieza, aunque siga presente en el personaje de don Gaspar el tipo del ilustrado adalid de la razón y el justo medio. 
Por otra parte, la cronología de la génesis del teatro menor autocensurado certifica manifiestamente que sus dos terceras partes fueron compuestas y estrenadas entre 1828 y 1837 . Si el estreno de El hombre gordo en enero de 1835 se entiende como un hito significativo en este quehacer dramático, no parece que sea entonces por representar el inicio de la dedicación de Bretón a las comedias breves, sino por ser una transición hacia el perfeccionamiento del subgénero. Se trataría, pues, de dos períodos diferenciados en la dramaturgia menor: en primer término, entre los años 1828 y 1835, Bretón habría aprendido y ensayado los elementos esenciales y las diferentes posibilidades de estructura y lenguaje dramático del teatro breve; el segundo período de esta trayectoria ocupó el lapso comprendido entre 1837 y 1862, cuando logró depurar su modelo hasta el punto de dar a sus piezas menores una funcionalidad diferente a la de servir de comedias de loa y circunstancias políticas.

Esta hipótesis se sustenta además con un rápido cotejo de la labor traductora del autor, la cual cumplió funciones propedéuticas en el conjunto de su dramaturgia. Su importancia ha despertado la curiosidad de críticos como Lafarga (1983-1988), Contreras (1992), Bittoun ${ }^{3}$ o Iñarrea (2000). Así pues, a propósito del teatro breve, hay que notar que su dedicación a las traducciones de vodeviles en uno o dos actos fue constante hasta, precisamente, el año 1835. Desde el estreno de El hombre gordo, sólo tradujo tres comedias breves del repertorio francés: ¿Se sabe quién gobierna?, en dos actos y representada el 3 de octubre de 1835; Un agente de policía o El espía sin saberlo, también en dos actos y llevada a escena el 27 de abril de 1836; y, finalmente, su última traducción en un acto catalogada por Cándido Bretón, La mansión del crimen o La víctima, estrenada en la Nochebuena de 1841. Las traducciones ceden lugar a la producción original de comediejas en el mencionado segundo período creativo, cuyo auge discurre hasta finales de 1845 con la representación de Frenología y magnetismo. Al llegar a este momento, Bretón había compuesto ya las cuatro quintas partes de su producción dramática y su teatro envejecía a favor de nuevas sensibilidades literarias como la «alta comedia». A partir de entonces, sólo escribirá ocho comedias breves adicionales hasta completar el catálogo de cuarenta y tres.

El carácter circunstancial del corpus autocensurado justifica, en mi opinión, un segundo criterio posible de división tomando como referencia una perspectiva cultural que enfoque el contexto de su escritura. Podrían proponerse entonces dos etapas claramente diferenciadas: la primera desvelaría una activa implicación del autor en actividades políticas, siendo su teatro breve un instrumento de propaganda; la segunda correspondería al retraimiento político motivado por su deseo de evitar adversidades que pudieran afectar negativamente a su estatus de persona pública.

\footnotetext{
${ }^{3}$ Bittoun Debruyne, Nathalie I. (1997). Las traducciones del teatro de Marivaux en España (1770-1835) [tesis doctoral]. Marta Giné i Janer (dir.). Lleida: Universidad.
} 
A la hora de diferenciar las diferentes etapas de la génesis del teatro menor, tanto este criterio ideológico como el estético previamente señalado no son excluyentes. En sí, ambos refuerzan la idea antes mencionada según la cual Bretón no creó conscientemente dos catálogos autónomos, ya que la técnica y recursos dramáticos empleados, tras una evidente evolución diacrónica, resultan similares. La lectura de todas las comedias breves permite notar la progresiva adecuación a nuevos estilos literarios que superaban el neoclasicismo moratiniano y la gradual depuración de recursos dramáticos, algo que no puede apreciarse si se tiene en cuenta únicamente el corpus tradicional de veinticinco piezas consideradas por la crítica posterior a Bretón. De la misma forma, valorar de manera autónoma el corpus autocensurado impediría apreciar tanto la depuración de las técnicas dramáticas a la que llegó el autor como las diferentes vicisitudes políticas, sociales y literarias que afectaron a su creación. En este sentido, a propósito de la existencia de las comedias breves autocensuradas, cabe extrapolar el juicio de Hartzenbusch sobre los distintos períodos creativos de Bretón de los Herreros. El crítico y literato distinguía tres épocas distintas: «desde 1824 a 1833 ofrece un aspecto de homogeneidad y reposo, en los diez años siguientes resultan la agitación y trastorno de un pueblo en lucha: desde 1843 la agitación va sosegándose» (Bretón de los Herreros, 1883-1884, I: LIV). Sendos períodos diferenciados por Hartzenbusch coinciden en esencia con algunos de los momentos políticos y sociales más señalados e importantes de la primera parte del siglo XIX. El que Bretón desarrolle entonces la mayor parte de su actividad literaria induce a pensar en la posible trascendencia de los acontecimientos más significativos ocurridos en dichos momentos respecto a su dramaturgia.

\section{GÉNESIS Y PROCESO DE AUTOCENSURA}

No sería novedosa esta idea de la politización del intelectual, dado que son muchos y variados los ejemplos al respecto. Recuérdese la paradigmática implicación de Rojas Zorrilla, Coello y Calderón de la Barca en la estrategia de exaltación patriótica orquestada por el Conde-Duque de Olivares ante la evidente decadencia imperial (Elliott, 1992). Más cercanas al caso que aquí ocupa son las opiniones del sentido utilitario que otorgaba Jovellanos (1966, II: 26) al espectáculo dramático y la intensa labor de propaganda y contrapropaganda teatral pergeñada por el invasor francés y patriotas españoles respectivamente durante los años de la Guerra de la Independencia (Larraz, 1974; 1988: 352-376), cuando la literatura «deja de comprenderse como representación poética de la realidad para convertirse en expresión patriótica de las diferentes corrientes de opinión de los autores y de la reacción condenatoria del pueblo español» (Rodríguez, 2012: 411). Todos ellos son ejemplos de una particular simbiosis que, lejos de ser traumática o restrictiva, se define en 
palabras de Foucault como una «red productiva que atraviesa todo el cuerpo social» (1979: 182). Alejándose de una concepción represiva de las relaciones del poder y los intelectuales, se podría determinar la politización del literato a partir de dos aspectos: en primer término, su posición en la sociedad burguesa en la que desarrolla su labor, cuya ideología le es impuesta; y en segundo lugar, como resultado del discurso que articula, puesto que en él muestra posibles relaciones políticas previamente inadvertidas (Foucault, 1979: 78). Éste pienso que es el caso de Bretón de los Herreros, quien, al insistir en las razones de mérito artístico para denostar y no reimprimir las comedias de circunstancias ligadas a acontecimientos políticos, no hacía sino admitir veladamente su sometimiento al poder establecido en cada momento histórico.

A tenor de esta idea, resultan significativos sus inicios literarios en el represivo ambiente político, social e intelectual del absolutismo fernandino de la Década Ominosa (1823-1833), en el que Bretón tuvo que abrirse camino superando su pasado afín al liberalismo veinteañista. Con la probable ayuda o patrocinio de Juan de Grimaldi (Gies, 1988), logró representar su primera comedia, A la vejez, viruelas, en una función dedicada a celebrar la onomástica de Fernando VII en el año 1824. Además de la oportunidad de iniciar una prometedora andadura como dramaturgo, dicha ocasión le permitía disimular sus antecedentes políticos e integrarse en una sociedad marcada por la represión y las purificaciones de elementos ajenos al régimen absolutista. Bretón de los Herreros reafirmó su condición de dramaturgo cortesano cuatro años después con el estreno de Amor y ligereza y El rival de sí mismo en agosto de 1828. Con motivo del regreso del monarca a la Corte, las dos piezas breves insistían en su función laudatoria celebrando la intervención real en la pacificación de la revuelta de los agraviados en Cataluña un año antes. Una tercera comedia breve, la traducción La codicia en posta, fue representada para la misma ocasión, según Roca de Togores (1883: 547), por lo que la función teatral completa fue encomendada al autor riojano.

La asunción de un discurso laudatorio, modelo de propaganda borbónica, se ejemplifica en la adopción de un subgénero literario paradigmático de este tipo de actos: la loa alegórica, cuya presencia en el teatro político del primer tercio del siglo XIX documentó Larraz (1988). A este respecto, con el título El templo de Himeneo, Bretón compuso a finales de 1829 una pieza breve poniendo fin a un año de escasa actividad literaria en el que sólo se representaron su traducción La astucia contra la fuerza o Los tres presos (1829) y su refundición Las paredes oyen (1829). Su característica distintiva es el uso intensivo de la alegoría y el simbolismo mitológico que articulaba el conjunto dramático, recursos que en sus anteriores obras breves de circunstancias aparecían exclusivamente en las escenas finales a modo de fin de fiesta. No es de extrañar la adopción del lenguaje alegórico y simbólico, puesto que tradicionalmente se ha asociado en el espectáculo teatral a la intencionalidad política (Andioc, 1988: 57). En esta ocasión, persiguiendo idénticos fines lau- 
datorios que las anteriores, El templo de Himeneo sirvió para celebrar el matrimonio de Fernando VII con su sobrina María Cristina de Borbón, apenas unos meses después del fallecimiento de la tercera esposa del monarca, María Josefa Amalia de Sajonia. El particular epitalamio de Bretón se unió de esta forma a los propios de la nutrida nómina de poetas que cantaron la ocasión, entre ellos Quintana, Gallego y Donoso Cortés (Roca, 1883: 67-68).

Coincidiendo con el deterioro ostensible de la salud del rey Fernando VII, la actividad encomiástica del teatro bretoniano se dirige precisamente hacia las personas de la joven reina y la futura heredera al trono, la princesa Isabel, nacida durante la estancia de Bretón en Sevilla como poeta de la compañía de Grimaldi y Joaquín Caprara (Gies, 1988: 88). Allí se puso en escena La sorpresa, escrita, al parecer, el año anterior (Roca, 1883: 76) y perdida según el catálogo de Cándido Bretón. La pieza se representó junto con la comedia extensa Achaques a los vicios para celebrar el cumpleaños de la reina María Cristina, aunque no han trascendido detalles de la circunstancia en cuestión.

La estancia en Sevilla fue provechosa y decisiva en la evolución de su estilo dramático. Su actividad literaria se intensificó tras su regreso a Madrid, aunque estuvo centrada en la traducción y en el desempeño de su dedicación a la crítica de espectáculos en El Correo Literario y Mercantil, periódico afín al absolutismo que dirigía José María Carnerero. A finales de 1831, estrenó su única comedia original de la temporada, Marcela o ¿A cuál de los tres?, que sintetizaba «la fórmula exacta de su sistema estético» (Roca, 1883: 87), una fórmula que continuó con su siguiente composición original, la comedia breve El músico y el poeta. Para entonces había transcurrido un año y medio y la situación política española era en extremo inestable. Se temía por la salud del rey, que había abdicado temporalmente en su esposa debido a un ataque de apoplejía. Y mientras los elementos reaccionarios, leales al infante Carlos María Isidro, hermano del rey, se posicionaban para asumir el control de los resortes del gobierno, los partidarios del liberalismo apoyaban sin ambages a la reina y los derechos dinásticos de la princesa Isabel esperanzados en un cambio de régimen. Ésta fue sin duda la posición de Bretón de los Herreros, como se demuestra en los contenidos apologéticos de El músico y el poeta. Originalmente fue escrita en noviembre de 1832 con la intención de celebrar la recuperación de la salud del rey, pero su estreno se produjo meses más tarde una vez modificadas las alusiones laudatorias. Este proceso de reescritura se dirigía a adecuar la representación a nuevas circunstancias políticas, relacionadas con la jura de Isabel como heredera al trono en virtud de la Pragmática Sanción de 1830 que derogaba la Ley Sálica. Junto a dicha obra, construida en base al patrón mostrado por su autor en Marcela o ¿A cuál de los tres? en lo que respecta a la variedad métrica, trama y personajes, se estrenan para la misma ocasión las piezas mitológico-alegóricas El templo de la Gloria y El triunfo de la Inocencia, cuyo estilo encorsetado contrasta no- 
tablemente con El músico y el poeta y las emparenta con la ya mencionada El templo de Himeneo.

Aunque estas composiciones breves, en particular los melodramas alegóricos, no inviten a ponderar a su autor como uno de los dramaturgos más relevantes del segundo tercio del siglo XIX, sí puede afirmarse sin error que son en extremo representativas de la instrumentalización de la literatura en aquellos años para preparar la instauración de la monarquía parlamentaria liberal. De hecho, con estas últimas tres piezas, Bretón se comprometió con el cambio político en ciernes, abandonando su interesada posición filoabsolutista anterior. Con la muerte de Fernando VII en septiembre de 1833, llegaron la transición al parlamentarismo constitucional y la guerra civil, que enfrentó a liberales y partidarios absolutistas del infante Carlos María Isidro. Para entonces, Bretón de los Herreros ya se había identificado con el ala moderada del partido liberal. La primera Guerra Carlista asoló el país durante casi siete años y para poner fin al conflicto hicieron falta todos los recursos materiales e intelectuales disponibles. La propaganda y la asunción del discurso gubernamental de la necesidad de la derrota de la facción fueron interiorizados por la sociedad partidaria del sistema político recién implantado.

A propósito de la institucionalización de los discursos y de la producción de la verdad, Foucault señalaba su inclusión dentro del concepto de poder y proponía la sugerente idea de la existencia de una «política general de la verdad» (1979: 187), entendida como el conjunto de discursos que en una sociedad se presuponen como verdaderos y que son favorecidos y producidos desde las instancias del poder. Esta concepción del poder es asociada por Foucault a su capacidad productora de saber y placer, mucho más significativa que la de coerción. Para no verse relegado en el nuevo orden político y social, Bretón hubo de participar activamente en ese entramado, en esa red productiva, desempeñando, según definición de Flynn (1978), las obligaciones de un poeta laureado. Por eso, una vez fallecido el rey Fernando VII y clausurado El Correo Literario y Mercantil, Bretón pasó a colaborar en 1834 en periódicos como El Universal, más tarde La Abeja, considerado el órgano del partido moderado que dominaba momentáneamente la escena política y que apoyó la labor del ministro Martínez de la Rosa. También en ese año fue nombrado por el ministro Javier de Burgos director del Boletín de Comercio, afín al liberalismo más progresista, pero el nombramiento derivó en escándalo inmediato ante las evidentes diferencias ideológicas entre el director y los redactores (Marrast, 1989: 319-320). Dado este anecdótico ejemplo de manipulación, cobra mayor sentido la publicación de la obra breve Los carlistas en Portugal o La tremenda expedición en El Universal de 15 de abril de 1834. Sus acotaciones escénicas, cargadas de ironía y mordacidad, invitan a creer que su destino final no eran los escenarios y que, al igual que la ulterior Entre santa y santo..., fue escrita para su publicación en la prensa periódica. 
Los carlistas en Portugal inaugura una serie de comedias breves patrióticas que denuestan la causa carlista y ridiculizan a su caudillo, el pretendiente Carlos María Isidro de Borbón. No se trata de una serie aislada o una disposición exclusiva y personal de Bretón, puesto que también intervinieron en otros ámbitos literarios escritores como Larra (Fernández, 2012) y Espronceda. Esta implicación generalizada de los intelectuales parece indicar que el anticarlismo patriótico bretoniano formaba parte de una campaña de propaganda progubernamental favorecida por las autoridades y que ejemplificaría el proceso productivo de la verdad auspiciado desde el poder que sugería Foucault. No es descartable que dicha implicación estuviera apuntalada con el nombramiento previo del autor como funcionario de la Subdelegación de Fomento de Madrid por designación directa del ya conocido Javier de Burgos, aunque también se han apuntado las presiones que sufrían los escritores desde ámbitos gubernamentales para escribir este tipo de composiciones (Gies, 1988: 217). Durante el decisivo año de 1835, Bretón estrenó El plan de un drama o La conspiración, Otro diablo predicador o El liberal por fuerza, 1835 y 1836 o Lo que es y lo que será y Un faccioso menos con el idéntico propósito de propalar el descrédito carlista que ponía en peligro el ideal de libertad a la vez que se conmemoraban hitos políticos o victorias militares. La serie se compone con celeridad y se estrena en un breve lapso de tiempo: los dos meses finales del año. Por aquel entonces, el ministro Mendizábal, que había ascendido al poder defendiendo la posibilidad de acabar el conflicto bélico por vía de un desorbitado incremento del esfuerzo económico del país financiado con empréstitos y desamortizaciones, veía comprometido su plan.

Precisamente, bajo el título, quién sabe si premonitorio, de El plan de un drama se propone una función patriótica «para aplicar su producto a las urgencias de la guerra». La comedia, como el resto de la serie y otras posteriores, reemplaza en su lenguaje dramático la alegoría propia de las loas absolutistas por elementos habituales en el teatro patriótico. Así, son inexcusables en todas ellas tanto versos patrióticos como himnos alusivos o canciones que habitualmente culminaban la representación en un acto sustitutivo del fin de fiesta del teatro aurisecular. Similares características se encuentran en Otro diablo predicador, destinada a celebrar la apertura de las Cortes el 16 de noviembre, acontecimiento considerado en ese momento «como el único medio de salvación del país» (Pirala, 1984, II: 360). El discurso patriótico se manifiesta en numerosas escenas e indirectamente se invita al alistamiento de voluntarios por medio del joven Marcelo, un patriota liberal que explica a su prometida, Clarita, las razones por las que se ha enrolado en el ejército cristino:

Clara mía, yo te adoro: lo sabes; pero tengo una Patria que merece, que reclama también mi amor. Entusiasta de la libertad, todavía no he consagrado a su triunfo otra cosa que sinceros deseos y fervientes votos. Llegó el momento de los verda- 
deros sacrificios: no poseo bienes de fortuna; pero soy joven, soy libre, y tengo un brazo que ofrecer a la Patria, y cuando tantos jóvenes bizarros corren voluntariamente a las armas contra la odiosa facción que pugna por esclavizarnos, no quiero yo que sus miradas me acusen de tibieza o de cobardía. Acabo de alistarme. Ya tiene un soldado más el valiente ejército de Navarra (Otro diablo predicador, esc. 6).

Si bien Ballesteros (2005: 144-148) no ofrece autoría a propósito de $U n$ faccioso menos, creo posible argumentar su atribución a Bretón de los Herreros no sólo gracias a las concomitancias que posee con otras obras suyas, sino también con las similitudes en la estructura de sendas piezas (Fernández, 2014: 176-186). Además de la coincidencia en la inclusión de un final deíctico, común en el teatro breve de Bretón (Bravo, 2002), los discursos patrióticos enunciados por los personajes también están presentes en Un faccioso menos. Se adopta ahora la perspectiva del personaje carlista decepcionado y convencido de la falsedad de los argumentos facciosos, por lo que términos como «ciego fanatismo», «guerra de abominación», «feliz desengaño», «hipócritas», «verdugos», son utilizados para caracterizar verbalmente el carlismo. Pese a todo, el discurso oficial se torna paternalista al proponer la reinserción del rebelde en la sociedad liberal:

No, no atraeré más sobre mi cabeza la maldición de mis conciudadanos, y ya que la inmortal Cristina es tan generosa, tan magnánima que abre todavía sus maternales brazos a los hijos que, o ignorantes o fascinados, no supieron ni pudieron comprender antes sus deberes, yo me acojo a su augusta clemencia y la juro eterna adhesión, eterna gratitud. El faccioso fanático se convierte en colono pacífico. El que llevó lágrimas y desolación a los ajenos hogares, bendecirá en el suyo la mano que le detuvo piadosa en el borde del abismo, y si otra vez empuño las armas no será para rasgar las entrañas de la patria, sino para defenderla contra sus opresores, al santo grito de ¡Isabel y Libertad! (Un faccioso menos, esc. 16).

Las tres comedias comparten, por tanto, objetivos y contenidos y deben interpretarse en su conjunto como una muestra de la mencionada «política general de la verdad» en la que se involucró una gran parte de los literatos en aquellos años críticos para la pervivencia del sistema liberal burgués. No es coincidencia que, con la caída del ministerio Mendizábal, quien tuvo que dimitir ante la evidencia del fracaso de su proyecto, Bretón se viera relevado de sus obligaciones de dramaturgo ad hoc. El poderoso magnate, cuya figura mesiánica se ponderó positivamente en su momento, fue objeto de una campaña de desprestigio en la que colaboraron decisivamente escritores como Espronceda con la publicación en 1836 de su opúsculo El ministerio Mendizábal (Marrast, 1989: 516-539), que redundaba en las demoledoras opiniones que había vertido Larra sobre el otrora influyente político (Fernández, 2012).

La siguiente colaboración de Bretón de los Herreros como autor de comedias de circunstancias se demoró un año, tras un convulso verano de 1836 en el que el sector más radical del liberalismo, con las figuras representativas de 
Calatrava y Mendizábal, retomó el control gubernamental gracias al motín de sargentos de La Granja. La nueva colaboración al servicio del extremo opuesto al moderantismo con el que se identificaba Bretón se justificaba con «el patriótico objeto de celebrar la heroica defensa y la salvación de la Invicta Bilbao», que había sido asediada por el ejército carlista en un intento de capturar un puerto comercial que facilitara al pretendiente Carlos las alianzas de potencias extranjeras afines a su causa. El estreno de Las improvisaciones ponía fin a una excepcional esterilidad creativa durante el año 1836, solamente justificable por su dedicación a su nuevo empleo como Bibliotecario segundo de la Biblioteca Nacional, un cargo que aseguraba su peculio y que podría considerarse como «la culminación de la carrera de un escritor» (Carnero, 1997: XXIV). Sin embargo, esta particular inactividad también puede justificarse en los términos de su relación respecto a los resortes del poder. Eugenio de Ochoa, en correspondencia particular con el conde de CampoAlange, atestigua el temor de Bretón a verse privado de su cargo como bibliotecario tras los acontecimientos de La Granja durante el verano de 1836 (Marrast, 1989: 564). Tras el relevo de Mendizábal por el moderado Istúriz el 15 de mayo anterior y el nuevo regreso al progresismo más radical, Bretón se encontró en la incómoda posición de disfrutar de un destino nombrado por el recientemente defenestrado duque de Rivas en un contexto de radicalismo y conatos de revolución constantes. La nómina de sus valedores mermó cualitativamente además con la precipitada salida del país de Juan de Grimaldi, quien se refugió en su Francia natal.

En Las improvisaciones, Bretón contribuyó a la celebración del levantamiento del cerco de Bilbao por parte del general Espartero en la Nochebuena de 1836. La significación de la fecha fue aprovechada por el gobierno para revertir el argumento de la impiedad con la que se asoció al liberalismo desde el sector más tradicional de la sociedad. Por eso Casilda, joven liberal a quien su tío, el carlista don Homobono, le impide casarse con el poeta y también liberal don Luís, no duda en afirmar que «El Emperador de Rusia es hereje y Jesucristo fue liberal» (esc. 3). Se insiste una vez más en la conversión ideológica y el desengaño del faccioso y, como sucediera en Un faccioso menos, el carlista de buena fe, Homobono, hace honor a su nombre y, tras reflexionar sobre los motivos de la salvación de Bilbao, encuentra explicación acorde a su carácter tradicional:

Creía, pues, que los pretendidos derechos de D. Carlos eran sólidos, positivos, imprescriptibles; creía que su causa era la del cielo... Pero los últimos sucesos de Bilbao me hacen ver las cosas de otro modo, y esta Gaceta extraordinaria es la vara de virtudes que quiebra las cataratas de mi entendimiento y arranca el velo a la estólida fe que me cegaba. ¿Qué derecho divino ni humano puede alegar un príncipe, que teniendo a su disposición un ejército formidable, que dominando aquellos países, que con un material de guerra suficiente para abrasar a toda Europa y con inmensos recursos de todo género no ha podido hacerse dueño de una 
villa indefensa? [...] No; su causa no es la del cielo, sino la del infierno. Dios le ha maldecido, y yo venero sus altos decretos. ¡Anatema al Pretendiente! ¡Viva Isabel II! ¡Viva la Libertad! (Las improvisaciones, esc. 10).

No me cabe duda de que al escribir Las improvisaciones el dramaturgo riojano condensó su experiencia de poeta cortesano y su creciente habilidad para escribir comedias breves como Una de tantas y Medidas extraordinarias $o$ Los parientes de mi mujer, estrenadas en ese mismo año. El resultado es una pieza notablemente más depurada que las anteriores obras de circunstancias, si bien continúa utilizando los recursos propios de este tipo de teatro: alusiones políticas, apología del sistema liberal, inclusión de música, versos patrióticos, el consabido himno final, etc. Como ya sucediera con El plan de un drama y con Otro diablo predicador, la comedia se dio a la imprenta, por lo que se conserva la nómina de autores y las respectivas composiciones patrióticas escritas para ser leídas por los actores durante la representación de la obra. El propio Bretón de los Herreros, Gil y Zárate o Joaquín Francisco Pacheco, figuran entre los nombres destacados.

Con el advenimiento del trienio moderado el 18 de agosto de 1837, Bretón no tuvo necesidad de volver a componer más dramas patrióticos hasta el estreno de La ponchada más de tres años después. La importancia de esta pieza es fundamental para comprender el proceso de autocensura posterior, porque el estrepitoso fracaso y el escándalo que acompañaron al estreno de dicha comedia condicionaron en buena medida el devenir literario y personal de Bretón. Como resultado, el dramaturgo se vio forzado a la cesantía, durante tanto tiempo evitada gracias a su habilidad de posicionarse políticamente, e incluso llegó a pensar en el exilio (Roca, 1883: 244-245), idea que recapacitó finalmente por la feliz acogida que el público madrileño dio a su comedia El cuarto de hora (1840).

Aunque los prolegómenos y el propio suceso fueron detallados por su biógrafo (Roca, 1883: 236-243), creo importante reconsiderar la trascendencia de La ponchada a la luz de la hipótesis defendida en este trabajo. De hecho, una somera lectura puede hacer pensar erróneamente que se trata de otra pieza circunstancial en torno al carlismo, concretamente sobre el desenlace del conflicto civil a favor del liberalismo constitucional, y en honor al héroe nacional, el general Espartero. Sin embargo, el velado propósito de La ponchada era celebrar el golpe de estado protagonizado por el progresismo que acabó con la abdicación y el exilio de la reina María Cristina y el nombramiento de Espartero como regente del reino. Una vez más, puede suponerse, como hace Le Gentil, que el dramaturgo fue inducido a componer su comedia «d'après intimidation» (1909: 40). De lo que no cabe duda es de que Bretón se vio en la incómoda tesitura de celebrar la victoria del partido progresista, contrario a sus propios ideales, pero de estricta necesidad para poder mantenerse en sus cargos administrativos que le proporcionaban estabilidad social y económica: 


\begin{abstract}
De même que la prudence la plus élémentaire lui interdisait de viser directement Espartero, il y aurait eu de l'ingratitude, de la part de l'administrateur de l'Imprimerie Nationale et du directeur de la Gaceta, à critiquer, même implicitement, Narváez. Le poète s'est donc rebattu sur les travers généraux, dans une satire que les chefs de file pouvaient estimer inoffensive puisqu'elle atteint la nation tout entière. Certes il était loisible, sans insulter ni les vainqueurs ni les vaincus, de rire aux dépens de l'employé ou de l'émigré (Le Gentil, 1909: 411).
\end{abstract}

El escándalo fue inmediato. Los milicianos nacionales partidarios de Espartero, presente asimismo en la función de loa, interpretaron negativamente las primeras escenas de la pieza, en donde se describía la picaresca y la relajación de los milicianos durante los preparativos de los fastos de recepción del caudillo. La situación fue tensa en extremo y el escritor tuvo que huir de Madrid para refugiarse en Burgos (Le Gentil, 1909: 41). Según el marqués de Molins, la explicación a este tole sin precedentes en la vida de Bretón se encuentra en la prensa de la época:

El mismo Eco de Comercio da la clave del motivo, que no es literario ni político, sino personal; la culpa, dice, es el no haber encomendado la composición del drama a persona poseída del espíritu dominante y mancomunada con el alzamiento, que hubiese hablado en el sentido popular de abundancia de corazón (Roca, 1883: 240).

Sean razones de índole personal o política, como más lógico parece ante los ejemplos aquí mostrados, la realidad es que Bretón se vio inmerso en la acritud de la cesantía. El 28 de noviembre, apenas dos meses después del infortunado estreno, fue cesado de su cargo de Bibliotecario mayor y Director de la Biblioteca Nacional. Se dedicó entonces a su quehacer literario y a labores en el Liceo Artístico de Madrid, alejado pues de la vida política. Su retraimiento coincide con la decadencia de su teatro, que él achacaba al incidente de La ponchada (Roca, 1883: 285) e incluso a la envidia (Bretón y Orozco, 1883a: XII). Así, durante tres años, hasta la derrota y exilio de Espartero en 1843 y la instauración de la conocida como década moderada hasta 1854 , Bretón no colaboró en ninguna función patriótica. Las noticias sobre su participación en la escritura de La sombra de Isabel I cobran sentido si se considera el clima positivo de la huída de Espartero y la ascensión al poder del moderado Luís González Bravo, perteneciente al círculo de amistades de Bretón, que se completó con el regreso de sus influyentes amigos exiliados Juan de la Pezuela y Patricio de la Escosura. Los sucesivos nombramientos de administrador de la Imprenta Nacional, director de la Gaceta y director de la Biblioteca Nacional, resarcieron a Bretón de las estrecheces sufridas.

Pese a que el dramaturgo riojano conoció de nuevo la cesantía durante el bienio liberal o progresista que se inició en septiembre de 1854, no volvió a verse involucrado en más escándalos políticos. De sus últimas tres comedias 
autocensuradas, El carnaval de los demonios y El peluquero y el cesante lo fueron siguiendo un estricto criterio estético. La única composición de carácter apologético, El Ebro, fue estrenada lejos de Madrid, en Tortosa, con motivo de la inauguración del canal navegable entre Mequinenza y San Carlos de la Rápita. Los únicos fragmentos laudatorios se producen al final de la comedia, cuando, a través de los preceptivos versos de loa, se pondera la figura de la entonces reina Isabel II como benefactora de las ciencias y el progreso técnico de la nación. Aún debería pasar más de una década para el advenimiento de la revolución de 1868, «La gloriosa», que derrocó a Isabel II y la forzó al destierro. Para entonces, Bretón había concluido su periplo creador y preparaba la última edición recopilatoria de sus obras literarias.

Esta recopilación en cuatro volúmenes de piezas dramáticas y un quinto con poesía y opúsculos en prosa apareció entre los años 1883 y 1884, pero Bretón la confeccionó a partir de la colección de sus obras que publicó en la Imprenta Nacional entre 1850 y 1851. Los criterios de selección resultaron ser similares, aunque la perspectiva que adoptó con el paso del tiempo es reveladora de una voluntad por ocultar parte de su obra literaria y de los motivos de su creación. Ésta se muestra sin ambages en el «Prefacio del autor» a las obras de 1850 al asumir la paternidad de únicamente las obras que el autor quería y debía aceptar, exceptuando las piezas de circunstancias compuestas «para objetos puramente políticos, muy plausibles, por supuesto, aunque no para todos, pero cuya oportunidad daba sólo veinte y cuatro horas, y a veces pocos días más su plausibilidad relativa» (Bretón de los Herreros, 1883-1884, I: LVIII). El rechazo de las comedias circunstanciales se hace sin intercesión de los círculos del poder o la censura gubernamental en aras del clima de concordia nacional reinante, llegando a pedir la «absolución» por sus partidismos pasados. Ningún interés le merecen dichas composiciones, puesto que no se mencionan en ningún momento los títulos o las circunstancias a las que se refería su comentario.

Hay que esperar a la aparición de la edición póstuma de las obras bretonianas para comprobar que la autocensura es un proceso continuado en el tiempo. Esta colección representó el testamento literario de su autor, quien seleccionó personalmente las comedias que debían darse a la imprenta. Además de la reproducción íntegra del prefacio de la recopilación de 1850 , se incluía en ésta un «Plan para una nueva edición de mis obras» (Bretón de los Herreros, 1883-1884, I: LXII-LXIV) en donde valoraba los errores y ponderaba los aciertos de sus composiciones dramáticas a la vez que expresaba su deseo de reimprimir ciertas obras dramáticas y descartar algunas otras. Sus argumentos insistían en el cuestionable mérito literario de alguna de sus creaciones o, simplemente, en su preferencia personal hacia ellas. Junto A la vejez, viruelas y Los sentidos corporales, primera y última de sus comedias; sus fracasadas zarzuelas Un novio pasado por agua (1852) y Cosas de Don Juan (1854); se excluían también de la edición las obras breves El Ebro y El pelu- 
quero y el cesante. Precisamente, su mención a Los sentidos corporales, estrenada a mediados de enero de 1867, indica que Bretón trazó su plan una vez retirado de la actividad teatral. El autor tampoco aquí hace alusión alguna al conjunto de comedias de loa absolutista y patriótica que ocupó buena parte de su atención en la década de 1830. Se menciona, en cambio, la elisión de un «embrión dramático», El carnaval de los demonios, que sí aparecía en la colección anterior, pero que entendía como de escaso mérito literario al ser una breve mascarada cuyo principal atractivo era la profusión de elementos escenográficos.

Además de estos comentarios del difunto autor, el instrumento más importante para discernir la verdadera naturaleza y alcance del proceso de autocensura es el minucioso y ya referido catálogo de composiciones bretonianas que elaboró el sobrino del autor, Cándido Bretón y Orozco (1883b). El epígrafe dedicado a las «Obras dramáticas» está condicionado, como él mismo advierte, por la falta de una recopilación íntegra de todas las obras compuestas por Bretón de los Herreros (Bretón y Orozco, 1883a: XVI). Aun así, su labor estaba avalada por su experiencia como funcionario en la Biblioteca Nacional madrileña (Bretón y Orozco, 1876: 22-26) y por el cercano conocimiento de su tío y su dramaturgia (La Ilustración de Madrid. 12.XI.1870, p. 11 ), por lo que hay que considerar dicho catálogo como una fuente primaria para el estudio de la obra bretoniana. Su conocimiento de ediciones impresas y manuscritos es notable, llegando a cuestionar copias de comedias como Jocó o el orangután (1831) que se creían originales. Pero, sin duda, el aspecto más relevante es el dominio que poseía de la práctica totalidad de comedias breves autocensuradas, que fueron catalogadas sin distinción junto con el resto de las piezas menores. De todas ellas, exceptuando El rival de sí mismo, apuntaba las circunstancias y las motivaciones políticas para las que fueron llevadas a los escenarios, algo que no reflejó en su estudio biográfico del autor que precedía al catálogo.

Esta catalogación resulta clave porque evidencia un doble criterio a la hora de interpretar la dramaturgia de Bretón de los Herreros. De este modo, como instrumento filológico para el estudio del corpus autocensurado, el catálogo se antoja como esencial por la riqueza de datos y por su visión totalizadora del teatro bretoniano. Por otra parte, su cotejo con las noticias y anécdotas biográficas revela una notable contradicción al comprobar que la biografía adolece de informaciones explícitas sobre dicho corpus autocensurado y las circunstancias en el que fue creado, manteniendo el criterio restrictivo del autor.

Dentro del proceso de autocensura, puede considerarse a Cándido Bretón como una figura destacada. Él fue el albacea literario de su tío y por tanto el último garante de la transmisión, pero también de la elisión, del conjunto de la obra literaria de Bretón de los Herreros. La escasa trascendencia que se le atribuía al teatro menor respecto a sus comedias extensas favoreció en cierta 
manera que la crítica posterior no percibiera dicha circunstancia. Tampoco la completa biografía de Roca de Togores, que toma parte de sus datos del bosquejo biográfico de Cándido Bretón, incide en la cuestión, por lo que la autocensura trasciende a dos de las fuentes documentales directas. El crítico más destacado que acometió la primera monografía sobre el dramaturgo riojano desde su fallecimiento fue George Le Gentil (1909), pero en su importante estudio no discriminaba el teatro breve del extenso, por lo que no fue percibida la autocensura a la que sometió Bretón parte de su creación literaria. Hay que esperar hasta la publicación del trabajo monográfico de Gerard Flynn (1978) sobre Bretón de los Herreros para encontrar una vaga referencia a la posibilidad de un número de comedias breves mayor de las veinticinco recogidas en la edición póstuma. Dicho crítico no duda en afirmar que «Bretón wrote thirty original comediejas and translated twenty-seven more from the French, so he was thoroughly at home in the genre» (Flynn, 1978: 114), y alude expresamente a la escritura política bretoniana citando un total de siete composiciones: Los carlistas en Portugal o La tremenda expedición, El Ebro, Las improvisaciones, Otro diablo predicador o El liberal por fuerza, El plan de un drama o La conspiración, La ponchada y El templo del Himeneo. Esta afirmación, aunque imprecisa en el número de comedias breves originales, pasó desapercibida igualmente para la crítica posterior. La publicación de un estudio centrado en el subgénero del teatro breve (Muro, 1991) y la primera edición de las comedias breves bretonianas (Muro, 2000) desde la antología de 1883-1884 ignoraron e incluso desdeñaron la existencia del grupo de composiciones rechazadas por Bretón de los Herreros, tergiversando el concepto del teatro menor del autor.

La anómala recepción crítica de la literatura bretoniana, excepcionalmente prolongada en el tiempo, también debe ser considerada una parte fundamental del proceso de autocensura. La crítica como cómplice de la ideología no es sino un lugar común, dado que toda interpretación puede verse contaminada por agentes externos y la crítica puede eliminar elementos de opinión susceptibles de chocar con el pensamiento dominante (Belsey, 1980: 30). Lo mismo puede decirse de las razones meramente estéticas que puedan aducirse al respecto. El que las obras autocensuradas se articulen en torno a circunstancias y alusiones políticas no las deslegitima para el estudio y consideración. Es más, este hecho les otorga una serie de particularidades que las hacen merecedoras de atención y análisis.

\section{4. ÚLTIMAS CONSIDERACIONES}

La diferenciación de un doble corpus dentro del subgénero del teatro breve no deja de ser una cuestión de matiz que, por las razones expuestas, no ha sido hasta ahora objeto de atención. Cuando su autor anunciaba en correspondencia 
privada con el marqués de Molins que la composición de sus obritas menores no era fruto de su entera y libre elección (Roca, 1883: 266), lo hacía con el convencimiento de que las constantes peticiones de actores y actrices que reclamaban el producto de su ingenio para realizar funciones de beneficio condicionaban el resultado literario, ya fuera por la precipitación con que las componía o por otras razones similares. La diferencia con las piezas autocensuradas es, como digo, de matiz, puesto que el proceso de génesis seguía una pauta similar: dada la circunstancia, la administración de turno o el político a la sazón le reclamaba una creación original que debía estar lista en cuestión de días o incluso horas. No parece sino que El plan de un drama, escrita al alimón con su amigo Ventura de la Vega, se compuso en clave autobiográfica, como haría posteriormente con El poeta y la beneficiada. Ambas recogen elementos significativos para comprender este procedimiento creativo.

La prolija cantidad de lagunas sobre la vida y las vicisitudes de Bretón de los Herreros habitualmente ha impedido la consideración general y el significado de la obra bretoniana en el contexto socio-político decimonónico. Los datos, cargados de inexactitudes y lugares comunes, se han transmitido en cadena y sin apenas respuesta crítica desde época contemporánea del autor hasta nuestros días. La prudencia y discreción de la que hacía gala el propio Bretón no ayudó en verdad a arrojar luz, sino más bien lo contrario. Baste recordar sus intrigantes palabras al valorar la elisión de numerosas composiciones para la recopilación de sus obras en 1850:

consideraciones de más de una especie me imponen silencio sobre muchas anécdotas y particularidades de mi vida escénica. Algunas de ellas no serían indiferentes a mis beneméritos suscriptores, porque pican en historia; pero espero de su discreción que se contentarán con lo dicho y con algunas notas especiales que, si gustan, irán leyendo interpoladas con el texto. Yo he ofrecido en el prospecto mis comedias, pero no la historia de mis comedias (Bretón de los Herreros, 18831884, I: LXI).

Quizás por esta imposibilidad de introspección a la que se ve forzada la crítica es por lo que habitualmente se ha prestado más atención a detalles curiosos como la pérdida de su ojo izquierdo o anécdotas similares. No es propósito de estas páginas el negar la utilidad de dichos datos, sino, más bien al contrario, intentar aportar respuesta esclarecedora a interrogantes de semejante naturaleza, de los que se pueden extraer conclusiones provechosas sobre la obra y vida del famoso dramaturgo. Sirva como ejemplo la noticia ofrecida sobre el homenaje de la empresa del Teatro Español en 1873 al recién desaparecido escritor que se aportaba en la introducción del presente trabajo. Poco puede decirse de la fortuna del proyectado mausoleo, pues en la actualidad los restos de Bretón se encuentran en el madrileño cementerio de San Justo, en el Panteón de Hombres Ilustres, donde comparte tumba con Francisco Villaespesa y Eduardo Marquina. También continúa suponiendo una incógnita la ausencia de Roca de Togores, amigo íntimo de Bretón, de la 
nómina de literatos que rindieron homenaje al poeta. En todo caso, podría estar relacionada con el delicado momento político en el que falleció Bretón, durante la inestable Primera República, cuando el marqués de Molins ejercía importantes servicios públicos. La breve biografía de Cárdenas (1891) apenas da noticia de la relación de amistad de ambos y no menciona el suceso de la muerte de Bretón de los Herreros. Sin embargo, esa escueta noticia de la Corona poética que daba pie a estas páginas acredita la estima que se tenía a su teatro menor en aquel tiempo: en las funciones de aquel lejano homenaje de 1873 se representaron sus comedias breves Una de tantas, Medidas extraordinarias, Ella es él, Mi secretario y yo y A lo hecho pecho. Todas ellas dignas representantes de su dramaturgia menor y habitualmente ponderadas por su autor y críticos diversos. Para obtener noticia de la existencia de las piezas menores rechazadas por el dramaturgo riojano y durante tanto tiempo ignoradas basta con referirse a otro homenaje a su numen literario. Así, de la fachada del coliseo construido en Logroño apenas unos años después de la muerte del poeta y bautizado con posterioridad como Teatro Bretón de los Herreros, penden dos placas alusivas a las comedias más representativas del autor y que parecen a la espera de la mirada del caminante curioso. Las únicas comedias breves que se constatan allí son, casualmente, dos comediejas autocensuradas: El Templo de Himeneo y El rival de sí mismo.

\section{BIBLIOGRAFÍA CITADA}

Aguilar Piñal, Francisco (1968). Cartelera prerromántica sevillana. Años 1800-1836. Madrid: CSIC.

Alonso Cortés, Narciso (ed.) (1928). Teatro de Bretón de los Herreros. Madrid: La lectura.

Andioc, René (1988). Teatro y sociedad en el Madrid del siglo XVIII. $2^{\mathrm{a}}$ edición. Madrid: Castalia.

Ballesteros Dorado, Ana Isabel (2005). Larra, Bretón de los Herreros y otros escritores anticarlistas (Teatro y ficción en la prensa liberal madrileña, 1833-1840). Palma de Mallorca: Calima.

Ballesteros Dorado, Ana Isabel (2012). Manuel Bretón de los Herreros: más de cien estrenos en Madrid (1824-1840). Logroño: Gobierno de La Rioja-Instituto de Estudios Riojanos, 2 vols.

Belsey, Catherine (1980). Critical practice. London-New York: Methuen.

Bravo Vega, Julián (1998a). «La comicidad verbal en el teatro breve de Bretón», en Miguel A. Muro Munilla (coord.), Actas del congreso internacional «Bretón de los Herreros: 200 años de escenarios», (Logroño, 14, 15 y 16 de octubre de 1996). Logroño: Instituto de Estudios Riojanos, pp. 45-67.

Bravo Vega, Julián (1998b). «Raíces áureas del teatro breve de Bretón de los Herreros: el enredo», en Felipe B. Pedraza Jiménez y Rafael González Cañal (ed.), La comedia de enredo. Actas de las XX Jornadas de teatro clásico de Almagro, 8, 9 y 10 de julio de 1997. Almagro: Universidad de Castilla la Mancha, pp. 321-351.

Bravo Vega, Julián (2002). El teatro menor de Manuel Bretón de los Herreros: aproximación a un género literario. Logroño: Ayuntamiento de Quel. 
Bretón de los Herreros, Manuel (1883-1884). Obras de don Manuel Bretón de los Herreros. Madrid: Ginesta, 5 vols.

Bretón de los Herreros, Manuel (1969). Marcela o ¿A cuál de los tres? José Hesse (ed.). Madrid: Taurus.

Bretón y Orozco, Cándido (1876). Breve noticia de la Biblioteca Nacional. Madrid: Imprenta, Estereotipia y Galvanoplastia de Aribau y Cía.

Bretón y Orozco, Cándido (1883a). «Apuntes sobre la vida y escritos de Don Manuel Bretón de los Herreros», en Manuel Bretón de los Herreros (1883-1884). Obras de don Manuel Bretón de los Herreros, I. Madrid: Imprenta de M. Ginesta, pp. III-XVII.

Bretón y Orozco, Cándido (1883b). «Catálogo de las obras de Don Manuel Bretón de los Herreros», en Manuel Bretón de los Herreros (1883-1884). Obras de don Manuel Bretón de los Herreros, I. Madrid: Imprenta de M. Ginesta, pp. XIX-XLVIII.

Caldera, Ermanno (1978). La commedia romántica in Spagna. Pisa: Giardini.

Cárdenas, Francisco de (1891). «Biografía del Marqués de Molins, académico de número». Boletín de la Real Academia de la Historia. 18, pp. 259-284.

Carnero, Guillermo (1997). «Introducción a la primera mitad del siglo XIX español», en Víctor García de la Concha (dir.). Historia de la literatura española. Siglo XIX, I. Madrid: Espasa Calpe, pp. XVII-C.

Carrión Gutiez, Manuel y Delgado, Juan (1996). «La huella de Bretón de los Herreros: bibliografía bretoniana», en Manuel Bretón de los Herreros (1796-1996). Madrid: Biblioteca Nacional (M.E.C.)-Gobierno de La Rioja, pp. 39-76.

Consiglio, Carlo (1947). «Algunas comedias de Bretón de los Herreros y sus relaciones con Goldoni», Berceo. 2, pp. 137-145.

Contreras Álvarez, Amparo (1992). Beaumarchais y su teatro en España. Barcelona: Universitat de Barcelona.

Cook, John A. (1959). Neo-Classic Drama in Spain. Theory and Practice. Dallas: Southern Methodist University Press.

Corona poética dedicada a honrar la memoria de Don Manuel Bretón de los Herreros (1873). Madrid: Imprenta de José M. Ducazcal.

Dengler Gassin, Roberto (1996). «El teatro clásico francés y su preceptiva a través de las reseñas de Bretón de los Herreros», en Ángel-Luis Pujante y Keith Gregor (ed.), Teatro Clásico en Traducción: texto, representación, recepción (Actas del Congreso Internacional. Murcia, 9-11 de noviembre de 1995). Murcia: Universidad de Murcia, pp. 437443.

Díez Taboada, Juan María y Juan Manuel Rozas (1965). Manuel Bretón de los Herreros. Obra Dispersa, 1. El Correo Literario y Mercantil. Logroño: Instituto de Estudios Riojanos.

Elliott, John H. (1992). «La propaganda del poder en tiempos de Olivares», en Francisco Rico (coord.). Historia y Crítica de la literatura española, 3. Siglos de Oro: Barroco. Primer suplemento. Barcelona: Crítica, pp. 75-80.

Fernández Urenda, Francisco Javier (2013). «Discurso del poder y voluntad de verdad en los artículos políticos anticarlistas de Mariano José de Larra», Neophilologus. 97.4, pp. 677-690. Doi: 10.1007/s11061-012-9343-z.

Fernández Urenda, Francisco Javier (2014). Política y autocensur en el teatro menor de Manuel Bretón de los Herreros: 1828-1861. Logroño: Universidad de La Rioja.

Flynn, Gerard (1978). Manuel Bretón de los Herreros. Boston: Twayne.

Foucault, Michel (1979). Microfísica del poder. $2^{\mathrm{a}}$ edición; Julia Varela y Fernando ÁlvarezUría (trad.). Madrid: Ediciones de La Piqueta.

Franco, Andrés (1984). «Manuel Bretón de los Herreros», en Stanley Hochman (ed.). McGraw-Hill Enciclopedia of World Drama: An International Reference, I. New York: McGraw-Hill, pp. 407-409.

Garelli, Patricia (1983). Bretón de los Herreros e la sua «formula comica». Imola: Galeati. 
Gies, David T. (1988). Theatre and politics in nineteenth-century Spain. Juan de Grimaldi as impresario and government agent. Cambridge: Cambridge University Press.

Gies, David T. (1996). El teatro en la España del siglo XIX. Juan Manuel Seco (trad.). Cambridge: Cambridge University Press.

González Herrán, José Manuel y Ermitas Penas Varela (1992). Cronología de la literatura española, siglos XVIII y XIX. Madrid: Cátedra.

Herrero Salgado, Félix (1963). Cartelera teatral madrileña, 2. Años 1840-1849. Simón Díaz, José (ed.). Madrid: CSIC.

Iñarrea Las Heras, Ignacio (2000). «Bretón traductor de Scribe», en Miguel A. Muro Munilla (coord.), La obra de Manuel Bretón de los Herreros. II Jornadas Bretonianas (Logroño, 2 al 5 de marzo de 1999). Logroño: Instituto de Estudios Riojanos, pp. 99-116.

Jovellanos, Gaspar Melchor de (1966). «Memoria para el arreglo de la policía de los espectáculos y diversiones públicas y sobre su origen en España», en Jovellanos. Obras escogidas. Ángel de Río (ed.). Madrid: Espasa-Calpe, 2 vols.

Lafarga, Francisco (1983-1988). Las traducciones españolas del teatro francés (1700-1835). Barcelona: Universitat de Barcelona, 2 vols.

Larraz, Emmanuel (1974). «La satire de Napolèon Bonaparte et Joseph dans le théâtre espagnol: 1808-1814», en Hommage à A. Joucla-Ruau. Aix-en-Provence: Département d'Études Hispaniques; Université de Provence, pp. 125-137.

Larraz, Emmanuel (1988). Théâtre et politique pendant la guerre d'Indépendance espagnole: 1808-1814. Aix-en-Provence: Université de Provence.

Lefevere, André (1997). Traducción, rescritura y la manipulación del canon literario. M. ${ }^{\mathrm{a}}$ Carmen África Vidal y Román Álvarez (trad.). Salamanca: Ediciones Colegio de España.

Le Gentil, George (1909). Le poète Manuel Bretón de los Herreros et la Société Espagnole de 1830 à 1860. París: Hachette.

Marrast, Robert (1989). José de Espronceda y su tiempo. Literatura, sociedad y política en tiempos del Romanticismo. Barcelona: Crítica.

Menarini, Piero, Patricia Garelli, Félix San Vicente y Susana Vedovato (1982). El teatro romántico español (1830-1850). Autores, obras, bibliografía. Bolonia: ATESA.

Mesonero Romanos, Ramón de (1967). Obras de D. Ramón de Mesonero Romanos. Carlos Seco Serrano (ed.). Madrid: Atlas, 5 vols.

Miret Puig, Pau (2004). Las ideas teatrales de M. Bretón de los Herreros. Logroño: Instituto de Estudios Riojanos.

Muro Munilla, Miguel Ángel (1991). El teatro breve de Bretón de los Herreros. Logroño: Gobierno de La Rioja-Instituto de Estudios Riojanos.

Muro Munilla, Miguel Ángel (ed.) (1999). Manuel Bretón de los Herreros. Obra selecta. Logroño: Universidad de La Rioja-Instituto de Estudios Riojanos, 3 vols.

Muro Munilla, Miguel Ángel (ed.) (2000). Manuel Bretón de los Herreros. Teatro Breve. Logroño: Universidad de La Rioja, 3 vols..

Ochoa, Eugenio de (1836). «D. Manuel Bretón de los Herreros», El Artista. 2, pp. 1-4.

Palacios Fernández, Emilio (1988). «El teatro en el siglo XVIII (hasta 1808)», en José $\mathrm{M}^{\mathrm{a}}$. Díez Borque (ed.), Historia del teatro en España, II. Madrid: Taurus, pp. 57-376.

Pirala, Antonio (1984). Historia de la guerra civil y de los Partidos Liberal y Carlista. Madrid: Turner-Historia 16, 6 vols.

Roca de Togores, Mariano (1883). Bretón de los Herreros: recuerdos de su vida y de sus obras. Madrid: M. Tello.

Roca de Togores, Mariano (1893). Bretón de los Herreros: estudio crítico. Madrid: La España Moderna.

Rodríguez Sánchez de León, María José (2012). «Literatura y política: la función de la literatura en las primeras décadas del siglo XIX», Revista de Literatura. LXXIV, 148, pp. 401-428. 
Rubio Jiménez, Jesús (1998). «Límites y limitaciones de la 'comedia de costumbres' de Bretón», en Miguel A. Muro Munilla (coord.), Actas del congreso internacional «Bretón de los Herreros: 200 años de escenarios», (Logroño, 14, 15 y 16 de octubre de 1996). Logroño: Instituto de Estudios Riojanos, pp. 101-122.

Simón Díaz, José (ed.) (1961). Cartelera teatral madrileña, 1. Años 1830-39. Madrid: CSIC

Fecha de recepción: 25 de marzo de 2013.

Fecha de aceptación: 11 de septiembre de 2013. 